\title{
Spinal Cord Injuries following Electrical Accidents
}

George Varghese, M.D., ${ }^{1}$ Mani M. Mani, M.D., ${ }^{2}$ and J. B. Redford, M.D. ${ }^{3}$ ${ }^{1,3}$ Department of Rehabilitation Medicine and ${ }^{2}$ Department of Plastic Surgery, The University of Kansas College of Health Sciences and Hospital 39th E Rainbow, Kansas City, Kansas 66103, U.S.A.

\section{Summary}

Injuries from high tension electrical current result in approximately 1000 deaths per year and account for 3\% of all major thermal injuries in the United States. Even though the complications from electrical injury can affect almost every organ system in the body, a neurological complication is perhaps the most common non-lethal one. 116 cases of electrical accidents among 1206 burn patients admitted to Kansas University Medical Center were reviewed. There were 5 cases of spinal cord injury which were detected from a few days up to four weeks from the injury. All had incomplete lesions. Two of them had quadriparesis, and 3 paraparesis. Clinical manifestations included motor and sensory involvement, predominantly motor. Possible mechanisms for the spinal cord damage include heating effect, electrogenic changes and vascular damage.

Spinal cord injury following an electrical accident is more frequently encountered than is generally recognized.

Key words: Spinal cord injury; Electrical accidents and complications.

\section{Introduction}

Injuries from high tension electrical current result in approximately 1,000 deaths and account for 3\% of all major thermal injuries every year in the United States (DiVincete et al., 1969; Farrell and Starr, 1968; Silverside, 1964; Skoog, 1970). This can cause damage to every organ system in the body and may simulate a crush injury rather than a thermal injury. While electrical injury can affect almost every organ system in the body, a neurological complication is perhaps the most common non-lethal one. Sensitivity of the nervous system to electrical damage has been well documented by experimental and by case studies. Critchley, 1934; Farrell and Starr, 1968; Skoog, 1970. Spinal cord injury is perhaps the most significant permanent sequelae of the electrical injury to the nervous system. Such injuries are more frequently encountered than is generally recognized. 
We describe five patients who had a spinal cord injury following electrical accidents.

\section{Methods}

One hundred and sixteen of the 1206 patients admitted to the Burn Unit at Kansas University Medical Center during the last 12 years had suffered electrical accidents. Eighty-five patients had evidence of contact injury and 31 had flash burn only. Among the 34 who had neurological injuries, 5 were noted to have spinal cord damage. Charts of these 5 patients were analysed for: 1 . onset of spinal cord lesion, 2. types of injury, 3. clinical manifestation, 4. recovery.

\section{Case 1}

A 19 -year-old man came in contact with a 34000 volt power line on $8 / 21 / 77$. He sustained a $60 \%$ burn. The likely entrance wound was in the skull and exit wound was in the right foot. X-rays of the skull showed normal findings. There was no history of fall. Weakness of both lower extremities was noted on the third day and 2 days later he became completely paralysed in one leg and partially in the other. Both lower extremities were spastic with brisk deep tendon reflexes, positive Babinski response, decreased position sense and patchy sensory loss. He developed neuropathic bowel and bladder disturbances. During the next 3 weeks there was some recovery in both lower extremities. He continued to progress even after discharge, but still has some bilateral lower limb weakness at the end of the third year of follow-up.

\section{Case 2}

A 66-year-old man came in contact with a high voltage power line on 3/18/81. He sustained $5 \%$ burns with the likely entry point in the left hand and exit in the shoulder with an arc burn involving back and face. There was no history of fall. When ambulation was attempted at the end of the first week, loss of balance and weakness were noted. Within another week he became quadriparetic witha C-7 level. Deep tendon reflexes were brisk and Babinski signs were present. Both position and vibration senses were decreased. He started improving after 2 weeks. At follow-up at one year, the patient had made a good recovery except for mild spasticity of the left side with decreased position sense over the right side.

\section{Case 3}

A 25 -year-old female was admitted on $2 / 17 / 80$ with a $15 \%$ full thickness burn which she sustained when her parachute got caught on a high voltage power line. The burn areas involved the anterior chest wall, and the right buttock and thigh. X-rays of the spine at the time of admission, were all within normal limits. She was discharged on $3 / 15 / 80$, when she was fully ambulatory without signs of neurological involvement. Four weeks later she complained of weakness and a tingling sensation in both lower extremities. Examination showed weakness 
of muscles in both lower extremities, the right more so than the left. She had decreased pin-pick sensation in both lower extremities. There was difficulty initiating micturation. E.M.G., urodynamic studies and repeat X-rays of the spine were all within normal limits. Re-evaluation about 2 weeks later showed almost complete recovery of muscle strength and normal sensory function.

\section{Case 4}

A 66-year-old farmer was admitted on 10/27/80 after standing on a metal ladder which came in contact with the high voltage power line. X-rays of the spine taken on admission and subsequently showed normal findings, except for degenerative changes. A week following admission he had 3/5 strength in both high flexors and quadriceps and $4 / 5$ strength in the dorsiflexor and plantar flexor muscles. No sensory deficit was detected. Deep tendon reflexes were brisk with Babinski responses. Following an extensive exercise program, he was discharged home on $12 / 23 / 80$. At that time he was able to ambulate with a walker. Subsequent follow-up showed complete recovery of both lower extremities.

\section{Case 5}

A 32-year-old male was admitted on $1 / 17 / 83$ after coming in contact with a high voltage power line. He had a third degree burn involving the right hand, left shoulder and a second degree burn in the face. He required a right below elbow amputation. Neurological examination within the first 24 hours did not indicate any deficits. X-rays of the spine were within normal limits. Towards the end of the second week, when ambulation was attempted, he was found to be ataxic and also had difficulty with coordination of the left hand. Detailed evaluation showed weakness below C-7 level, brisk deep tendon reflexes, ankle clonus and bilateral positive Babinski responses. Sensory examination was within normal limits. C.T. scan of the cervical spine carried out at this time showed normal findings. After 2 weeks he started to improve and by the end of 3 weeks he had made an almost complete neurological recovery except for brisk reflexes.

\section{Results}

None of these 5 spinal cord injured patients had evidence of weakness nor of any neurological involvement at the time of admission, nor evidence of mechanical injury to the spine, nor electrical injuries near the spine. Clinical manifestations of spinal cord involvement are summarized in Table 1. Three patients with a history of fall had normal X-rays of the spine, ruling out the possibility of fracture or dislocation. Motor weakness was noted in the first patient on the third day and in 2 patients, the onset was noted towards the end of the first week. In these two patients, the weakness was noted for the first time when ambulation was attempted.

The remaining two patients demonstrated weakness about 4 weeks from injury. The entrance and exit wounds were on the same side in 2 patients and on the opposite side in the other three. One had an arc burn from the shoulder to the face, but did not have any deep wound in the neck area. Clinically all patients 
Table 1 Spinal cord involvement

\begin{tabular}{lr}
\hline Number of Patients & (Total 5) \\
\hline Incomplete Lesions & 5 \\
Quadriparesis & 2 \\
Paraparesis & 3 \\
Motor \& Sensory Involvement & 3 \\
Motor Only & 2 \\
\hline
\end{tabular}

had an upper motor neuron type of lesion and in all it was incomplete. Two patients had quadriparesis and the other 3 paraparesis. Three had both motor and sensory involvement, and 2 had only motor involvement. Motor involvement was much more predominant in all patients. One patient (Case 1) had significant paraparesis from the third day and remained paraparetic even at the end of 3 years. In two other patients, complete recovery occurred in a matter of 2 to 3 weeks and in about 3 months in the fourth patient. The fifth patient also made a significant recovery even though he still had minimal residual weakness at the end of one year follow-up. Two patients reported urinary symptoms, but only one had a documented neuropathic bladder.

\section{Discussion}

Electrical injuries are partly the result of conversion of electrical energy to heat energy within the body. There are several factors influencing the extent of damage (Skoog, 1970; Solemand Fischer, 1977).

1. Amperage. Experimental studies have shown that 25 milliamperes or more can cause permanent damage to the nerves and blood vessels and 70 milliamperes or more could be lethal.

2. Voltage. High tension injuries (more than 1000 volts) are generally more dangerous.

3. Resistance. Tissue with high resistance like tendons, bones and skin tend to have serious damage; whereas tissues with low resistance like blood vessels, liver and spleen have the least damage.

4. Type of Current. Alternating current is much more dangerous than direct current for two reasons: (a) The tetanic contraction can fix the victim to the source of current; (b) Alternating current can interfere with the respiratory and cardiovascular centres.

5. Pathway of the current. Current that flows from one hand to the other or to the feet causes the worst damage. Current entering and exiting through the same extremity causes the least damage.

6. Duration of the contact. The longer the duration, the more extensive the damage.

Complications from electrical injury can affect almost every organ system in the body. Neurological involvement includes cerebral lesions, spinal cord lesions and peripheral nerve damage. (Hartford and Zeffen 1971; Solem and Fischer, 1977). The incidence of neurological complications is reported to be anywhere from 40-75\% (Hartford and Zeffen, 1971; Remensynder, 1980). 
Several possible mechanisms of injury to the nervous system have been explained. These are:

1. Heating effect.

2. Electrogenic changes.

3. Vascular changes.

The direct heating effect can cause necrosis of the cord. Experimental studies have shown that the passage of electricity through the nervous system can cause changes in the protein molecules. (Christensen et al., 1980; Farrell and Starr, 1968; Panse, 1970). Such protein changes in the cells can result either in death or of an abnormality of the cell. This electrogenic effect on the cells has been compared with changes following irradiation. It is also important that the existence of a latent period between the exposure and neurological order may also be as a result of such structural and biological changes. The third, and perhaps the most documented damage is vascular change (Bloom and Ugland, 1967; Christensen et al., 1980; Critchley, 1934; Langworthy, 1929). Many experimental studies and also autopsy findings have shown petechial hemorrhages, dilatation of the perivascular space and other ischemic changes. Small blood vessels can either rupture or develop thrombosis after the passage of electricity. Mechanical trauma to the spinal cord is a possibility since many of the victims are working on a ladder or on a power line resulting in a fall immediately after the electrical contact (Holbrook et al., 1970). In our series, 3 patients had a history of a fall, but none of these patients had any evidence of mechanical trauma to the spine. Hyperextension injury to the spinal cord is another possibility (Holbrook et al., 1970). In our series, all patients, especially those with the history of a fall, had a period following trauma when they were neurologically intact, suggesting that the fall was not the likely cause of spinal cord damage.

Since most of the lesions are incomplete and patients survive the accident, only a few autopsy findings are available to illustrate the microscopic and macroscopic changes in the spinal cord. Critchley (1934) reported 3 autopsy studies. Common findings in his series were petechial hemorrhages in the spinal cord, chromatolysis of the pyramidal and anterior horn cells, cavitation, swelling and softening of the cord. Jackson, et al. (1965) reported one autopsy in which swelling of the spinal cord, segmental myelopathy, reactive gliosis and perivascular infiltration were noted. In another autopsy report by Levine, et al. (1975) the findings included Wallerian degeneration, cavitation, destruction of neurons and myelin degeneration. Experimental studies reported by Critchley, Panse and Langworthy all reported similar findings (Christensen et al., 1980; Langworthy, 1929; Panse, 1970). To summarize the pathological findings are: swelling of the spinal cord, softening of the cord, petechial hemorrhages, chromatolysis of anterior horn cells, fragmentation of axons, cavitation, reactive gliosis and myelin degeneration.

The clinical manifestations of spinal cord involvement are generally divided into two groups:

1. Immediate. This usually happens in the first 24 hours. Patients usually complain of weakness and paraesthesiae, and symptoms usually resolve within a matter of a few hours.

2. Delayed. The delayed onset of spinal cord injury can happen anytime, from 
Table 2 Reports of incidence of spinal cord injury following electrical accidents

\begin{tabular}{lr}
\hline Levine, N. S. (1975) & 2 out of $11(2 \%)$ \\
DiVincente, F. E. (1969) & 2 out of $65(3 \%)$ \\
Baxter, C. R. (1970) & 12 out of $45(27 \%)$ \\
Silverside, J. (1969) & 3 out of $14(21 \%)$ \\
Hyslop, G. H. (1949) & 3 out of $50(6 \%)$ \\
Varghese, G. (1985) & 5 out of $85(6 \%)$ \\
\hline
\end{tabular}

a few days up to two years. They are usually incomplete and predominantly motor. They can be progressive, and full recovery is uncertain.

Panse (1970) collected 20 cases from the literature and added 9 cases of his own. According to him, the spinal cord form may resemble either motor neuron disease or transverse myelitis.

Levine, et al. (1975) from their review of the literature, including Panse's series, collected 27 cases of transient paralysis, which resolved in all of these patients within 24 hours. They also described 40 patients in which the onset was more than a few days, up to 2 years following trauma. None of these patients made a complete recovery and only two had any significant recovery. Most had pain and paraesthesiae which resolved, but weakness persisted.

In our review of the literature, we could not find any statement about the incidence of spinal cord injury following electrical accidents. One of the main reasons for this is that in most of the published series there are only 2 or 3 patients. In the six series, including our own, where complications are discussed, the incidence of spinal cord injury varied anywhere from 2 to 27 percent. (Table 2). The two series with a large incidence of complications (Baxter, 1970 and Silverside, 1964) were rather small in the total number of patints. Most of the larger series reported an incidence of from 2 to 6 percent. In our series, we detected 5 cases of spinal cord involvement among 85 patients, giving an incidence of 6 percent. This constitutes 15 percent of all neurological complications following electrical accidents. Other complications from electrical injuries include renal failure, muscle damage, cataract and extensive tissue necrosis requiring amputation.

\section{Conclusion}

The incidence of spinal cord injury following an electrical accident is 6 percent in our series. There was no evidence of deep local burns related to the level of spinal cord injury, indicating that the injuries are secondary to conductive current rather than due to a direct heating effect on the cord. There was also no evidence of mechanical trauma to the spine in any of our patients. We could not find any correlation between entrance-exit point and spinal cord damage, to specifically suggest that any particular pathway is more dangerous than the other. All of our patients had incomplete lesions; 3 were paraparetic and 2 quadriparetic. Contrary to some of the previous reports, 3 of our patients who had a delayed onset of neurological abnormality made an almost complete recovery. The clinical manifestations were motor and sensory, with the former being predominant.

Spinal cord injury following electrical accidents may be more frequent than is generally recognized. Sometimes the lesions are transient and may go 
unnoticed. Because of serious injuries to other body systems it is easy for spinal cord symptoms to go unnoticed in the early stages. At times the lesion is suspected only when these patients attempt to ambulate. Physicians should be aware of this complication and evaluate the patients periodically for possible spinal cord involvement.

\section{Résumé}

Dans les Etats Unis, les accidents dus aux courants électriques àvoltage élevé causent à peu près milles morts, et trois pour cents des maladies de brulure par an. Les maladies de brulure électrique peurvent affecter nimporte quel système du corps humain-Mais les maladies du système nerveus ne sont pas fatales. Dans cet article, les auteurs ont revisé 116 cas d'accidents électriques parmis 1206 cas de brulures traiteés àl'université de Kansas Medical Center. Parmis ces malades, il y avait 5 cas de malades de la moelle épiniaire—leur maladie était découverte quelques jours à quelques mois après l'accident-Tous les lésions étaient partielles-Deux d'entre elles étaient tétraparétiques et 3 étaient paraparétquies. Par examin médical, tous avaient des défets du mouvement et de la sensation mais surtout du mouvement-Les mécanismes qui ont pu causé la maladie de la moelle épiniaire sont: L'effet du chauffage, l'effet de la polarisation électrique et l'effet sur les vessaux sanguins.

On croit que la maladie de la moelle e'piniaire après un accident électrique est plus fréquente que nous pensions-Dans beaucoup de cas, la maladie est découverte quand le malade essaye de marcher.

\section{Zusammenfassung}

Hochspannungs Strohm versursacht ungefähr 1,000 Todesfälle jedes Jahr and Zählt für 3\% aller schweren Brandunfälle in den U.S.A. Brandunfälle Können Komplikationen in allen Organen bewerken, am häufigsten betreffen sie aber das Nerven-System. In diesem Artikel werden 116 Elektrounfälle von 1,206 Patienten die in dem Kansas University Medical Center behandelt wurden, beschrieben. 5 von diesen Patienten hatten ein bechädigtes Rückstrenmark. In allen diesen Fällen war die Beschädigung erst von ein paar Tagen bis 4 Wochen nach dem Unfall zu bemerken. In allen Fällen war die Bešhädigung nicht total. 2 hatten Quadriparesis and 3 hatten Paraparesis. Das klinische Bild zeigte Motor- and Gefühls-Betei leigung aber hauptsächlich Motor. Etliche Möglichkeiten für die Rückenmarkbeschädigungen sind: Hitze, elektrogene Veränderungen und Blutgefäss-veränderungen, Wir glauben dass Rüekenmarkbeschädigungen durch Brandunfälle öfter vorkommen als im Allegemeinen vermute-wird.

Öfters wird die Beschädigung erst vermutet wenn der Patient einen abnormalen Gang oder Schwäche beim Gehen zeigt.

\section{References}

BAXTER CR 1970 Present concepts in the management of major electrical injury. Surg. Clinics of North America 50:1401-1418.

Bloom S, Ugland OM 1967 Peripheral nerve injuries in electrical burns. Scandinavian Journal of Plastic and Reconstructive Surgery, pp. 45-53.

Christensen JA, Sherman RT, Balis GA, Wuamet JD 1980 Delayed neurologic injury secondary to high-voltage current with recovery. The Journal of Trauma 20:166-168.

CRITCHLEY M 1934 Neurological effects of lightening and of electricity. The Lancet, pp. 68-72.

DiVincente FC, Moncrief JA, Pruitt BA, Jr. 1969 Electrical injuries: A review of 65 cases. The Journal of Trauma 9:497-507.

FARRELL DF, STARR A 1968 Delayed neurological sequelae of electrical injuries. Neurology 18:601-606.

HARTFORD C, ZEFFEN SE 1971 Electrical injury. The Journal of Trauma 11:331-336.

HOLBROOK LA, BEACH FYM, SILVER JR 1970 Delayed myelopathy: a rare complication of severe electrical burns. British Medical Journal 12:659-660.

JACKSON FE, MARTIN R, DAvid R 1965 Delayed quadriplegia following electrical burn. Military Medicine, pp. 601-605.

LANGWORTHY OR 1929 Neurological abnormalities produced by electricity. Journal of Nervous and Mental Disease 84:13-26. 
Levine NS, Atrins A, McKell DW, Peck SD, Pruitt BA 1975 Spinal cord injury following electrical accidents: case reports. The Journal of Trauma 15:459-463.

PANSE F 1970 Electrical lesions of the nervous system. In Vinken PJ, Bruyn GW (Eds.),

Chapter 13, Handbook of Clinical Neurology. Amsterdam, North Holland 7:344-387.

REMENSNYDER JP 1980 Amputations and high-tension electrical injuries. Inter-Clinic Information Bulletin 17:1-6.

Silverside J 1964 The neurological sequelae of electrical injury. The Canadian Medical Association Journal 91:195-204.

Skoog T 1970 Electrical injuries. The Journal of Trauma 10:816-830.

Solem L, Fischer RP, Strate RG 1977 The natural history of electrical injury. The Journal of Trauma 17:487-492. 